\title{
HOW TO UPGRADE YOUR BUSINESS FACING THE PANDEMIC COVID-19 (MENGUBAH PETAKA MENJADI PELUANG) PADA UMKM BINAAN KADIN PROVINSI JAWA BARAT
}

\author{
${ }^{1 *}$ Neneng Susanti, ${ }^{2}$ Tanti Irawati Mukhlis, ${ }^{3}$ Vincentia Wahju Widajatun, \\ ${ }^{4}$ Nugi Muhammad Nugraha, ${ }^{5}$ Muhammad Bayu Aji Sumantri, ${ }^{6}$ Supardi \\ Universitas Widyatama \\ Email : ${ }^{1}$ neneng.susanti@,widyatama.ac.id
}

Manuskrip: Okt-2020; Ditinjau: Okt-2020; Diterima: Nov-2020; Online: Jan-2021; Diterbitkan: Jan-2021

\begin{abstract}
ABSTRAK
Tujuan dari kegiatan pengabdian kepada masyarakat ini adalah untuk memberikan penyuluhan dan menggerakkan masyarakat agar berusaha lagi mencari peluang dalam siatusi pandemik ini sehingga bisa bertahan dalam perekonomian dengan menciptakan inovasi baru.

Metode pelaksanaan pengabdian dengan mengadakan penyuluhan, sistem pemaparan secara online, diskusi dan tanya jawab. Dalam materi penyuluhan diberikan gambaran mengenai cara mencari peluang pada masa pandemik inidenga harapan memberikan wawasan baru bagi parapelaku usaha yang nantinya dapat diterapkan dan ditularkan ke masyarakat luas.

Target materi pada kegiatan penyuluhan PKM tercapai dengan cukup baik, dapat dilihat dari hasil pemahamana dari materipenyuluhan. Untuk menerapkan hasil dari penyuluhan masih diperlukan kepercayaan masyarkakat untk menggunakan media aplikasi, meskipunbanyak keuntungan yang ditawarkan cara belanja online. Beberapa langkah untuk dapat mempertahankan eksistensinya di pasar di era digital seperti, refokus pelanggan dan industri rethinking, merancang strategi sosial dan digital dan mengembangkan kapabilitas organisasi.
\end{abstract}

\section{Kata Kunci : Pelatihan, UMKM, Online}

\section{PENDAHULUAN}

Pandemik Corona Virus Disease 2019 (COVID-19) diumumkan WHO (World Health Organization) tanggal 11 Maret 2020. Kejadian Covid-19 yang dilaporkan kepada publik pertama kali tanggal 31 Januari 2020 di Wuhan, Propinsi Hubei, RRC. Memasuki Minggu ketiga April 2020 terdapat 170.000 lebih korban yang meninggal, yang sembuh sebanyak 640.000 dari total yang terkonfirmasi positif sebanyak lebih dari 1,4 juta orang (www.corona.help.com, April 2020) Suci (2020). Dalam pengamatan Bhargavaa et al. (2020) menemukan bahwa angka kelangsungan hidup yang tinggi akan memberikan kontribusi positif bagi pertumbuhan ekonomi. Di sisi lain Covid-19 telah mengakibatkan angka kematian (mortality) yang tinggi. Covid-19 telah menimbulkan economic shock, yang 
mempengaruhi ekonomi secara perorangan, rumah tangga, perusahaan mikro, kecil, menengah maupun besar, bahkan mempengaruhi ekonomi negara dengan skala cakupan dari lokal, nasional, dan bahkan global.Taufik (2020). Salah satu dampak pandemic COVID-19ialah UMKM di Indonesia, berdasarkan data dari kementerian koperasi yang menggambarkan bahwa 1.785 koperasi dan 163.713 pelaku Usaha Mikro Kecil dan Menengah(UMKM) terdampak pandemik virus corona (COVID-19).Kebanyakan koperasi yang terkena dampak COVID-19 bergerak pada bidang kebutuhan sehari-hari, Sedangkan sektor UMKM yang paling terdampak yakni makanan dan minuman. Kementerian Koperasi dan UMKM mengatakan bahwa koperasi yang bergerak pada bidang jasa dan produksi juga paling terdampak pada pandemic COVID-19. Para pengelola koperasi merasakan turunnya penjualan, kekurangan modal, dan terhambatnya distribusi.Sementara itu sector UMKM yang terguncang selama pandemi COVID-19selain daripada makanan dan minuman, juga adalah industri kreatif dan pertanian.

Jawa Barat merupakan wilayah yang mempunyai UMKM berjumlah 4.545.874 UMKM merupakan penggerak ekonomi di Jawa barat dengan menyerap $74 \%$ tenaga kerja di tahun 2016. Wabah covid-19 kini menjadi pandemi global setelah diumumkan oleh Badan Kesehatan Dunia dan penyebaran yang begitu cepat menjadikan Covid -19 sebagai topik utama di berbagai negara. Tidak terkecuali di Indonesia jumlah positif terinfeksi virus corona atau Covid-19 semakin hari semakin meningkat. Pada tanggal 24 Maret 2020 korban meninggal sudah mencapai 55 orang dengan jumlah sembuh menjadi 30 orang. Meskipun angka kesembuhan Covid-19 terus meningkat, namun penyebaran kasus Covid-19 juga mengalami peningkatan hingga terjadi ketidakpastian dan akan mempengaruhi laju perekonomian global.Moody's investor Service memprediksi pertumbuhan ekonomi akan mengalami perlambatan pada angka 4,8\% terhadap Produk Domestik Bruto (PDB). Nilai ini jauh dibawah pertumbuhan ekonomi tahun 2019 yang berada di angka 5,02\%. Dan perlambatan ini akan diprediksi akan berlanjut sampai tahun 2021 meskipun disertai dengan sedikit penguatan sebesar 4,9\% (Rohmah, 2020)

Adanya gejolak ekonomi yang begitu luar biasa UMKM dinilai mampu menghadapi perlambatan ekonomi terkait dengan kondisi terkini. Ketua Umum Asosiasi UMKM Indonesia (Akumindo) Ikhsan Ingrabatun memperkirakan omset UMKM di sektor non kuliner turun $30-35 \%$ sejak Covid-19 penyebabnya adalah penjual yang hanya mengandalkan tatap muka atau pertemuan antara penjual dan pembeli secara fisik. meskipun dampak dari Covid-19 ini sangat dirasakan berbagai sektor industri namun tidak berarti pelaku UMKM harus berhenti dalam menjalankan usahanya. Akan tetapi UMKM masih bisa berupaya tetap menjalankan usahanya melalui sistem online (e-marketing) dimana hal ini tidak akan melanggar aturan pemerintah terkait aturan social distancing. Melalui peranan teknologi kegiatan usaha dan pendistribusian barang masih bisa dilakukan. Hal ini dilakukan dengan tujuan agar usaha UMKM tidak berhenti begitu saja dan pendistribusian barangakantetap dapat berjalan. Menurut Rohmah (2020) dengan adanyaNorma baru bagi pelaku bisnis di kala mengahadapi pandemi Covid-19 yang mengharuskan pelaku usaha untuk melek 
teknologi. Hal ini juga nantinya akan berlaku pasca Covid-19 yang mengharuskan pelaku UMKM recovery bahkan untuk beradaptasi dengan norma baru yang mengharuskan bersinggungan dengan teknologi.Kemajuan teknologi saat ini mendorong manusia untukmelakukkan kegiatan yang lebih cepat dan mudah. Kemajuan tersebut tampak padabidang telekomunikasiAmri (2020). Adanya kemajuan telekomunikasi ini membuat hubungan antarmanusia dalam hal komunikasi menjadi tanpa batas dan tanpa hambatan terutama adalah jarak. Internet merupakan kemajuansalah satu dalam bidang teknologi komunikasi yang tumbuh begitu pesatnya. Internet memberikan manfaat kemudahan dalamkomunikasi dan memiliki kepentingan tertentu.

\section{METODE PELAKSANAAN KEGIATAN}

Metode pelaksanaan dalam kegiatan program pengabdian kepada masyarakat ini diawali dengan melakukan kerjasama dengan ketua Kamar Dagang dan Industri Jawa Barat. Survey awal yang dilakukan oleh tim pengusul untuk menjajaki dan mengetahui permasalahan yang dihadapi pelaku UMKM, disampaikan pada dasarnya keberadaan amar Dagang dan Industri Jawa Barat untuk membantu para pelaku usaha Adapun metode pelaksanaan dilakukan secara daring pada tanggal 05 Juni 2020 melalui google meet.Metode kegiatan pengabdian yang digunakan adalah metode ceramah dipilih untuk menyampaikan konsep. Pemanfaatan laptop dan Liquid Crystal Display (LCD) membantu peserta pelatihan lebih mudah memahami dan mengingat materi pelatihan relatif banyak dengan waktu pelatihan yang terbatas.

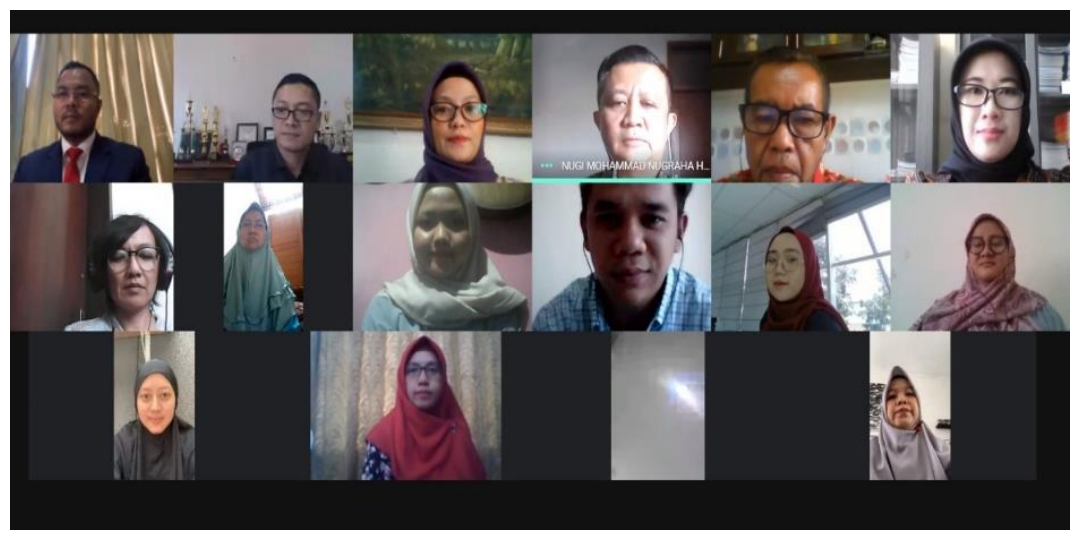

Gambar 1. Pelaksanaan Kegiatan Melalui Google Meet

\section{HASIL DAN PEMBAHASAN}

Saat ini perilaku konsumsi masyarakat Indonesia yang semakin mengarah kepadagaya hidup digital. Namun peluang ini tidak dimanfaatkan semua pelaku usaha untuk memiliki perspektif usaha dengan digital marketing. Meskipunbanyak pelaku usaha kini mulai menggunakan digital dan media sosial sebagai media untuk memasarkan produknya, namun sayangnya jumlahnya masih sangat terbatas. Pemanfaatan pemasaran dengan media digital (digital marketing) masih dirasakan belum maksimal jika dibandingkan dengan pertumbuhan jumlah pengguna 
internet yang drastis. Berdasarkan hasil riset McKinsey, baru sekitar 30\% usaha di Indonesia yang menggunakan instrumen digital dalam mengembangkan usahanya. Melihat hal ini, dapat kita simpulkan bahwa potensi digital marketing di Indonesia masih sangat besar.

Popularitas sosial media semakin berkembang dan telah terbukti menjadi salah satu cara promosi paling efektif. website social networking bisa memiliki hingga jutaan pengguna di seluruh dunia. Sedikit saja anda berpromosi kepada kumpulan user ini, anda sudah bisa mendapatkan pelanggan yang cukup banyak untuk produk bisnis anda. Social media telah mendominasi tidak hanya dunia pemasaran online namun juga dalam dunia komunikasi global. Micro blogging seperti twitter seringkali menyebarkan informasi jauh lebih cepat dibandingkan dengan media lainnya. Bahkan sebelum anda bisa melihat sebuah informasi faktual di TV, anda sudah bisa membacanya langsung dari social media, Susanti (2012).

Melihat hal ini, dapat kita simpulkan bahwa potensi digital marketing di Indonesia masih sangat besar.Adanya UMKM akan memberikan pengaruh besar dalam pertumbuhan perekonomian Indonesia terutama dalam menciptakan dunia kerja dan terutama dalam mendukung pendapatan rumah tangga. Berkembangnya UMKM diharapkan dapatmemacu laju perekonomian di tengah lesunya dunia usaha yang terjadi saat ini ditengah pandemi. Pemanfaatan konsep pemasaran melalui penggunaan teknologi digital diharapan UMKM mampu berkembang dan menjadi pusat kekuatan ekonomi.

Hasil program pengabdian pada masyarakat ini adalah adanya transferknowledge keadaan mitra tentang apa kendala yang dihadapi selama menjalankan usahanya dan kendala yang bertambah ketika terjadinya pandemic ini serta membahas bagaimana konsep kerja digital marketing pada e-business. Sehingga tingkat literasi mitra pada inovasi baru dan e-business bisa meningkat serta bisa mengaplikasikannya dalam kehidupan sehari - hari dan semoga mitra bisa masuk kedalamnya serta meningkatkan pangsa pasar usaha mitra itu sendiri. Pada kuisioner yang telah disebarkan memberikan hasil pada pelatihan apa saja yang dibutuhkan oleh para mitra usaha sebagai tambahan untuk mengembangkan lagi usahanya.

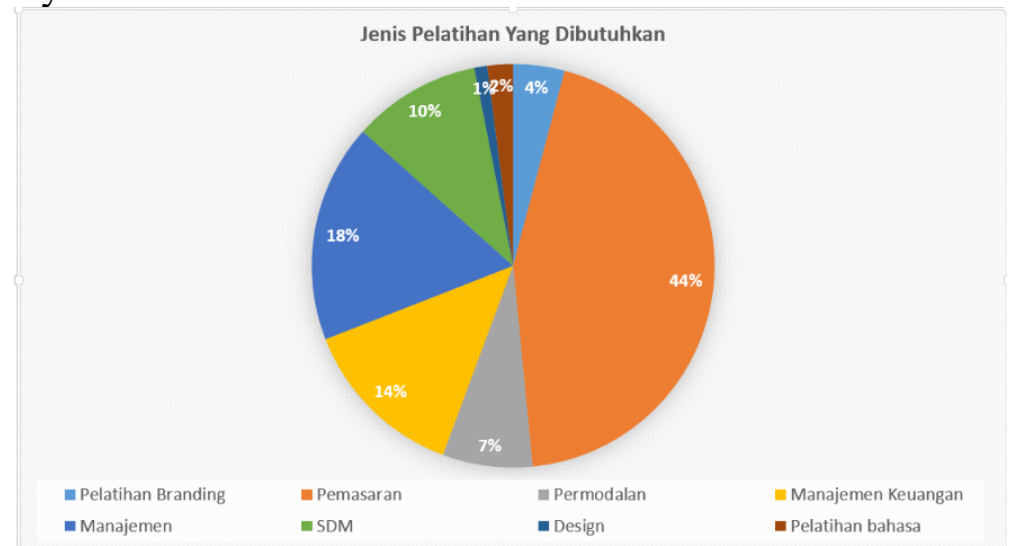

Sumber : Peserta UMKM Jawa Barat (data diolah kembali, 2020)

Gambar 2. Hasil Respon Pada Pelatihan Yang dibutuhkan 
Menurut gambar diatas, dapat dilihat bahwa responden banyak sekali yang memilih pelatihan dibidang pemasaran, dapat dikatakan bahwa pemasaran ini sangat berpengaruh sekali pada keberlangsungan usaha yang dijalankan para pelaku UMKM sehingga hal ini menjadi komponen penting yang wajib dipelajari oleh semua pelaku usaha baik dalam bentuk offline maupun online. Dengan kondisi pandemic semua pelaku usaha dapat melakukan pemasaran online yang dapat di akses pada e-business.

Pada tahapan awal kami merumuskan bersama bagimana kondisi mitra terdampak covid-19 yang sesungguhnya dengan melakukan identifikasi masalah apa saja yang menjadi kendala pada usaha mereka, sebagian besar memang belum begitu memahami tentang e-business itu sendiri dan takut untuk mengaplikasikannya dalam kehidupan sehari-hari. Kemudian menganalisa kebutuhan mitra seperti apa dalam rangka peningkatan literasi terhadap inovasi baru langkah-langkah tepat melewati masa-masa kritis saat pandemic terhadap usahanya dan e-business itu sendiri. Program yang sederhana namun efektif adalah dengan cara pelatihan dan sharing session akirnya dipilih dalam kegiatan ini. Menunjuk pembicara yang lebih memahami strategi bisnis, kemudian menyiapkan bahan-bahan maupun materi sosialisasi dan pelatihan untuk mitra dari.

Kegiatan pokok dari pelatihan umkm ini adalah memberikan pembelajaran kepada umkm untuk belajar melalui berbagai layanan program pendidikan luar sekolah, contoh ketrampilan menggunakan komputer, belajar desain, atau ketrampilan yang lain yang mampu meningkatkan soft skill dan hard skill umkm belajar sebagai pendamping ketentuan yang berlaku Gunarti (2020).Dari kegiatan ini dampak positif yang sudah bisa dilihat adalah mitra menjadi lebih paham tentang pengaruh teknologi dalam kegiatan ekonomi dan usaha. Dengan peningkatan tingkat pemahaman mitra terhadap e-business akan menjadikan mereka lebih berhati-hati dan waspada terhadap setiap tawaran dan kegiatan yang berhubungan dengan e-business serta mampu memanfaatkan peluang-peluang yang ada yang ditawarkan pada e-business seperti peminjaman peer to peer yang syaratnya tentu tidak sedetail persyaratan pengajuan kredit ke Bank.

\section{KESIMPULAN DAN SARAN}

Perkembangan UMKM di Jawa barat sekaligus di Indonesia menunjukkan pola yang baik. Adanya dukungan dari pemerintah melalui cara-cara tertentu memengaruhi angka pertumbuhan jumlah unit usaha mikro, kecil, dan menengah. Pemanfaatan sarana teknologi dan komunikasi, alokasi kredit usaha dari perbankan untuk rakyat, serta menurunnya tarif pajak PPh Final menjadi beberapa faktor yang mendorong perkembangan UMKM di Indonesia. Meski begitu, pertumbuhan ini dinilai masih lambat karena beberapa faktor pendukung tersebut dinilai belum terlalu efektif.

Dengan adanya berita UMKM yang sudah terhubung dengan marketplace digital saat ini dapat dikatakan tepat untuk mempercepat UMKM go digital. Pemahaman mitra terhadap e-business menajdi meningkat sehingga menjadikan mereka lebih berhati-hati dan waspada terhadap setiap tawaran dan kegiatan yang 
berhubungan dengane-business serta mampu memanfaatkan peluang-peluang yang ada yang ditawarkan pada $e$-business.

\section{DAFTAR PUSTAKA}

Amri, Andi. 2020. Dampak Covid-19 Terhadap UMKM Di Indonesia. Jurnal Brand, Volume 2 No. 1, Juni 2020 ISSN: 2715-4920

Bhargavaa, A., Dean T. Jamisonb, Lawrence J. Lauc, Christopher J.L. Murray, 2020, "Modeling the effects of health on economic growth", Journal of Health Economics. 20, 423- 440

Gunartin, Soffi, Feb Amni, Pusat Kegiatan Belajar Masyarakat Sebagai Tempat Alternatif Menumbuhkan Kemandirian Wirausaha Warga Belajar (Studi pada PKBM Insan Karya Pamulang Tangerang Selatan, Jurnal PEKOBIS Volume 3 Nomor 2 Oktober 2018

Haque, MG., Munawaroh, Sunarsi, D., (2020). Analysis of SMEs Culinary Marketing Strategy During Covid 19 Pancemic: A Study at "Sate Bebek Cilegon" Resto in Cilegon, Banten. International Journal of Education, Information Technology, and Others. Vol.3. Issue 2

Maddinsyah, A., Hidayat, D., Juhaeri, J., Susanto, D., \& Sunarsi, D. (2020). Desain Formulasi Dan Implementasi Bisnis Strategik Dengan Pendekatan Business Model Canvas (BMC) Terintegrasi Kerangka Integrated Performance Management System (IPMS) Pada Koperasi Asperindo. Inovasi, 7(2), 6776.

Rohmah, Farida dan Husni Awali. 2020. Urgensi Pemanfaatan E-Marketing Pada Keberlangsungan UMKM di Kota Pekalongan di Tengah Dampak Covid19. Jurnal Ekonomi dan Bisnis Islam. Volume2 Nomor 1, Januari - Juni 2020

Suci, Fellyanda. 2020. Cerita Lengkap Asal Mula Munculnya Virus Coronadi Wuhan

Sunarsi, D. (2020). Implikasi Digitalisasi Umkm. Digitalisasi UMKM, 57. books.google.com

(2020). The Influence of Supply Chain Strategy on Employee Performance on Small and Medium Business in Beringharjo Market, Yogyakarta- Indonesia. International Journal of Supply Chain Management. Vol. 9, No. 5

Susanti, Neneng dan Sakina Ichsani. 2012. Industri Kreatif Memerlukan Banyak Promosi. Seminar Nasional Kewirausahaan dan Inovasi Bisnis II 2012 (SNKIB II 2012) Universitas Tarumanagara, Jakarta, 18 September 2012ISSN No: 2089-1040

Taufik dan Eka Avianti Ayuningtyas. 2020. Dampak Pandemi Covid-19 Terhadap Bisnis dan Eksistensi Platform Online. Sekolah Tinggi Ilmu Ekonomi IPWI Jakarta p-ISSN 1411-710X e-ISSN 2620-388X 